\title{
TRIPS and Article 27.1
}

\section{Shreya Mazumdar*}

Christ University, School of Law Bangalore and Symbiosis Law School, Pune, India

\begin{abstract}
The member countries of WTO have to abide by the rule of TRIPs which all the member state does as it is mandatory. But the TRIPs criteria are too strict to be implemented by all the member states equally. Thus there are exceptions, over compliance, textual silence and flexibilities provided by the TRIPs agreement for the countries to frame their national laws as per the need of its society but in compliance with TRIPs. Therefore it is the choice laid on the country to abide by the TRIPs strictly or have a lenient implementation of it. When it come to the interpretation of the term "inventive step" TRIPS provides a flexibility by not define the term. It is left on the various countries to interpret the terms according to its convenience. The World Trade Organization (WTO) Trade Related Aspects of Intellectual Property Rights Agreement has set out a minimum standard in order to protect intellectual property which included patent for pharmaceuticals has been criticized by various countries because it resulted in the increase level of patent protection on drug prices. The TRIPS Agreement has become an important tool in order to standardize the protection of pharmaceuticals in the world and this is actively sought by government of developed countries and also by big pharmaceutical companies. The Agreement consists of various IPR issues in a manner that no international convention had dealt with previously including both substantive and enforcement rules in some area with considerable detail. The article is an effort to search for a concrete guideline when it comes to interpretation of "inventive steps" and focusing on different countries implementing it.
\end{abstract}

Keywords: World Trade Organization (WTO); Article 27.1; Inventive step; Non obviousness

\section{Introduction}

The World Trade Organization (WTO) Trade Related Aspects of Intellectual Property Rights Agreement has set out a minimum standard in order to protect intellectual property which included patent for pharmaceuticals has been criticized by various countries because it resulted in the increase level of patent protection on drug prices ${ }^{1}$. TRIPS offers safeguard to remedy negative effect of patent protection or abuse but it does not specify whether and how countries can make use of these safeguards when patents increasingly show barrier to medicine access ${ }^{2}$.

Thus for the Fourth WTO Ministerial Conference which was held in Doha 2001, Qatar adopted a Declaration on TRIPs and Public Health which gave sovereign rights of government to take measures to protect public health ${ }^{3}[1]$.

Before the implementation of the TRIPs Agreement the international legal framework for IPRs was made up of treaties and conventions that was administered and negotiated by the World Intellectual Property Organization (WIPO) ${ }^{4}$. Though these legal framework could hardly be considered to properly regulate the protection of IPRs on the global level as mostly the developing countries did not ratify any of the main convention on IPRs ${ }^{5}$. By 1980s the developed countries became dissatisfied with this framework as the trend was changing with the high technologies industries and technology commercialization ${ }^{6}$. They were especially vulnerable to trade distortion caused by IP

${ }^{1}$ Ellen F.M.'T Hoen, TRIPS, Pharmaceutical Patents and Access to Essential Medicines: Seattle, Doha and Beyond, http://cdrwww.who.int/intellectualproperty/ topics/ip/tHoen.pdf (last updated on 20/3/2016 at 11:11 PM).

2lbid.

${ }^{3} /$ bid.

${ }^{4}$ Baskaran Balasingham, Trade in Pharmaceuticals Under the TRIPs Agreement, 11 U. C. Dublin L. Rev. 12011.

${ }^{5}$ lbid.

${ }^{6} / \mathrm{bid}$. infringement ${ }^{7}$. TRIPS were made up to be more focused on market stimulated regulation and leading by the developed countries rules ${ }^{8}$. The industries in the developed countries demanded countries for a higher protection of their exclusive rights on the third country market ${ }^{9}$. It also complained about the losses that they suffer a lot of losses due to piracy and counterfeited products worldwide ${ }^{10}$. The United States and EU started to adopt unilateral and bilateral measures to impose the third world countries to implement higher standard IP protection so that the exported products are secure ${ }^{11}[2]$.

It was only in Uruguay Rounds the TRIPS Agreement was concluded after protracted negotiation. It was a task of bringing in to compromise both developed and developing countries.

TRIPS with its 151 member countries it was the first multilateral trade agreement that has incorporated intellectual property provisions. In Uruguay Rounds of the General Agreement on Tariffs and Trade (GATT) 1994 as a part of negotiation TRIPS was an annex to the agreement creating the WTO. There is a variety of reaction over a period of time with respect to application of the World Trade Organization's dispute resolution procedures to the TRIPS agreement. Initially the
${ }^{7}$ Ibid.
${ }^{8} \mathrm{Ibid}$.
I
${ }^{10}$ lbid.
${ }^{11}$ bid.

*Corresponding author: Mazumdar S, LL.M., B.A. LL.B. (Hons.) Christ University, School of law Bangalore and Symbiosis Law School, Pune, India, E-mail: shreyamazumdar2012@gmail.com

Received October 01, 2016; Accepted October 28, 2016; Published November 06, 2016

Citation: Mazumdar S (2016) TRIPS and Article 27.1. Intel Prop Rights. S1: 008. doi: 10.4172/2375-4516.S1-008

Copyright: (C) 2016 Mazumdar S. This is an open-access article distributed under the terms of the Creative Commons Attribution License, which permits unrestricted use, distribution, and reproduction in any medium, provided the original author and source are credited. 
decision made to enforce the treaty by WTO's dispute resolution process was a loss for developing countries. There was a fear that it would lead to an enormous amount of litigation against the developing countries. The other set of fear was that it would lead to an explosion of litigation against developing countries and distort the domestic intellectual property policy making. There are few disputes before WTO panels that were involved in the violation of the TRIPS Agreement and there are a fewer that has been brought for the developing countries and there are none that has withdrawn the trade concession.

The TRIPS Agreement is mandatory for global intellectual property law and every member nation shall make sure that domestic laws confirm to TRIPS standard else there is a risk that is sanctioned by the $\mathrm{WTO}^{12}$ [3]. It is considered mandatory due to the fact that the member states have to abide by the TRIPs agreement and they have to make sure that the domestic laws is at par with TRIPS when it comes to intellectual property rights. If such conditions are not abided by the member states then the consequences are posed under WTO and in addition to that the member country will not quality for the benefits under WTO.

Under Paris Convention for the Protection of Industrial Property mentions free to exclude areas from patentability with regards to special rules for certain types of invention ${ }^{13}$. Requirement of patentability can also be added ${ }^{14}$. Article 27.1 includes a general obligation of patentability addressing in this manner the pharmaceutical industry with respect to prevailing regimes prior to TRIPS ${ }^{15}[4]$.

By November 2015 WTO has 162 member countries and in order to join TRIPs a country has to become a member of the $\mathrm{WTO}^{16}$ [5]. In order to join WTO a country has to establish criteria relating to various aspects of trade and all member states must agree to the accession ${ }^{17}$ [6]. TRIPs are the first and foremost essential multilateral trade agreement which incorporate intellectual property provision ${ }^{18}$. TRIPs follow the Paris and Berne Convention in order to protect patent and copyrights but it contains provisions relating to trademarks, trade secrets, semi conductor chip, geographical indication and patent ${ }^{19}[6]$.

The TRIPs agreement established a new set of international minimum standard on Intellectual Property Rights ${ }^{20}$. Thus when these member countries adopt TRIPs agreement they have to make it compatible with the existing legislation for it to comply with TRIPs ${ }^{21}$. In order to fully implement the developed countries were given a transition period of one year ${ }^{22}$. For the developing countries members and members in transition has to make the amendment by $1^{\text {st }}$ January 2000. Least Developed countries members have until January 2006 been

${ }^{12}$ Donald S. Chisum, Patentability Under TRIPS: The Need for Uniformity, The Indian Journal of Law and Technology Vol.2, 2006.

${ }^{13}$ Patents: Subject Matter and Patentability Requirements, CY564-Unctad-v1 November 29, 2004.

${ }^{14}$ Ibid.

${ }^{15} /$ bid.

${ }^{16} \mathrm{https} / / /$ www.wto.org/english/thewto_e/whatis_e/tif_e/org6 e.htm, visited on $18 / 3 / 2016$ at 6:23 P.M.

${ }^{17}$ Maria Victoria Stout, Crossing The TRIPs Nondiscrimination Line: How CAFTA Pharmaceutical Patent Provisions Violate TRIPS Article 27.1, 14 B.U. J. Sci. \& Tech. L. 1772008.

${ }^{18} / \mathrm{bid}$.

${ }^{19} \mathrm{lbid}$.

${ }^{20}$ Paul Vandoren, TRIPS: An EU Perspective, 7 Int'I Intell. Prop. L. \& Pol'y 79-1 2002

${ }^{21}$ lbid

${ }^{22}$ Ibid. entitled to request an additional transitional period to comply with the TRIPs requirements ${ }^{23}$. It has been a complaint by the developing and the least developed country members that have criticized the TRIPs Agreement as they believe that the rules were too stringent for them to follow thus preventing them from using intellectual property regime that adequately meet their policy need ${ }^{24}$. Thus the question stands what amounts to 'inventive step' under Article 27.1 of TRIPs in respect of pharmaceuticals industry?

It is provided in Article 1 that member countries may not implement extra extensive protection than that is required by TRIPs Agreement ${ }^{25}$. This gives a leeway for the developed and the developing countries in order to adjust their legal order in accordance to the TRIPs Agreement ${ }^{26}$. There are number of flexibilities that have been provided by TRIPs Agreement for the member state in order to determine their own approach relating to the intellectual property rights and access to pharmaceuticals ${ }^{27}$. For instance the terms "new", "inventive step" or "industrial application" under Article 27.1 showed a space for flexibility to the member states in order for them to reach the minimum standard. Thus the countries will know the minimum standards it has to comply by for the access to medicine. These flexibilities by WIPO has been defined as, "legal tools that countries can use as they see fit in their national development plans and within the framework of the mandatory standards of international obligations. ${ }^{28 "}$ Flexibility means that there are various interpretations in which TRIPs agreement can be abided by the national law in order to comply by the national interest and also comply by TRIPs agreement ${ }^{29}$ [7] for instance nature of the invention should be defined and patentability criteria should be regulated within the framework of TRIPs Agreement rules. So the second question stands, if there is a minimum standard that is followed when it comes to implementation of 'inventive step' under Article 27.1 of TRIPs followed by the member countries?

\section{TRIPS over compliance ${ }^{30}$}

With the transaction of the TRIPS Agreement in 1994, developed nations effectively made consistence with certain basic protected innovation measures a prerequisite of participation in the WTO. The TRIPS Agreement may be viewed as an example of overcoming adversity for international law. In comparison to the international treaties, the TRIPS Agreement has enjoyed a broad confirmation as well as large amounts of national compliance. Indeed, one may even contend that it has been excessively effective as in comparison to other international convention it is TRIPS that has been complied by maximum of the member states. Though there were impressive uncertainty in its terms and a purported responsibility in order to maintain minimum standards the states have not exploited these flexibilities in order to implement the treaty in ways which is in consistent with local needs and values like Novartis case in India where it was held by the Supreme Court that minute changes and improvements to drug Glivec did not amount to any innovation that deserved any at give far more noteworthy insurance than is required by the terms of the treaty itself like states with indigenous population may grant more extensive protection for traditional knowledge [8].
${ }^{23} /$ bid.
${ }^{24} /$ bid
${ }^{25}$ /bid.
${ }^{26} / \mathrm{bid}$.
${ }^{27}$ Ibid.
${ }^{28} /$ bid.
${ }^{29} / \mathrm{bid}$
${ }^{30}$ Molly Land, Rebalancing TRIPS, 33 Mich. J. Int'I L. 433 2011-2012. 


\section{TRIPS flexibilities ${ }^{31}$}

One of the criticism of TRIPS that has been discussed is of the implementation of the domestic intellectual property laws by the member states in ways that foster innovation and protect human health and welfare. It has been mentioned by Peter Yu, that TRIPS Agreement is a part of an "international enclosure movement" and it has "enclosed the policy space of individual countries and they have to comply by the one size-fits-all legal standards which ignores their national, local, technological and public health interests." The capability to tailor intellectual property policies to domestic condition is difficult due to several reasons. Firstly, the policies may vary from country to country in order to protect human health and welfare. The debate is about the access to medicine where depending on the health needs and resources a state may limit patent rights on few medicines in order to make them affordable. The important part of making the intellectual property right suitable to protect human right extends to all types of intellectual property and all kinds of rights [9].

Right to free expression had been protected by the fair use exception of copyright law. Patent rights may be limited in order to make sure that the continued development of the scientific research and the shared benefits of the research.

The kind of human right and the public policy problem presented by intellectual property rights also varies the wide patentability available for basic science shows different problems that is related to the undergrowth of narrower rights given in the field where advances are incremental. Secondly, in order to promote innovation and development intellectual property policy must be in conformity with the local condition. It is a problem to have one size fits all approach to all innovation in an international agreement as states may have heterogeneity in preference of their innovation approaches. The intellectual property policies bring in more innovation and development in one context are different from those necessary in another. Data which is exclusive like indigenous knowledge resources can provide incentives for research into traditional medicines for the country. Due to the rapid change in the digital environment there is a capacity to make flexibilities which is important for developed nations as well as for developing nations. Thirdly, to comply with the local values and concerns the intellectual property policies must be tailored. The policies often involves consideration of issues that is pertains to local values. Thus imposing of TRIPS Agreement of "one size fits all" solution must limit through the creation of substantive ceilings, amendments to TRIPS or external norms such as human rights which has some problem to comply with the goals and structure of the treaty itself.

TRIPs agreement permits the following flexibilities which is ${ }^{32}$ firstly the nature of the invention should be defined and patentability criteria should be regulated within the framework of TRIPs Agreement rules;

Secondly, patent right exception should be established. licenses.

Thirdly, there shall be grant government use and compulsory

Fourthly, there is a range of option in case of protection of data for submitting of regulatory purposes.

Fifthly, there shall be determination of country based policies in case of exhaustion of rights and allow parallel importation of medicines.

\section{${ }^{31}$ lbid}

${ }^{32}$ Supra note 31
Sixthly, there shall be utilization of "unfair commercial use" and option of "protection of undisclosed test data".

It is said that these flexibilities are ambiguous and hence it should be implemented at the national level ${ }^{33}$. For instance Article 27.1 mentions "new", "inventive step" or "industrial application" in its provision but it does not provide a definition to it. The terms are flexible for the countries to implement as required according to the societal needs and legislative intent [10].

By its own terms, the TRIPS Agreement forces just minimum principles. Despite the fact that they are required to regard its procurements, WTO states might, however should not be obliged to, implement in their law more broad protection than is required and might be allowed to decide the proper technique for executing the procurements of this Agreement inside of their own legitimate framework and practice. Researchers have started to mention the ways in which there shall be a better implementation of TRIPS agreement itself or the new policies that has to be implemented provided that there is space for flexibility to the member state in order for them to reach the intellectual property norms. In particular, there are a few unique sorts of exceptions contained in the Agreement that furnish states with extensive slack in implementing their commitments under the bargain like the developing countries members and members in transition has to make the amendment by $1^{\text {st }}$ January 2000 . Least Developed countries members have until January 2006 which later extended to 2021 which entitled to request an additional transitional period to comply with the TRIPs requirements. Even the terms "new", "inventive step" or "industrial application" under Article 27.1 showed a space for flexibility to the member states in order for them to reach the minimum standard of the intellectual property norm.

\section{Textual silence}

There is a requirement for the state to establish minimum standard of protection and in order to do so without any discrimination the treaty does not mention the ways in which the state should go on achieving such goals. The states are required to follow that "patents shall be available for any inventions, whether products or processes, in all fields of technology, provided that they are new, involve an inventive step and are capable of industrial application," but the treaty does not give a definition to "new", "inventive step" or "industrial application". One of the instances is of India where the flexibility has been utilized by judging the patentability of "new drugs" by stating that "both new uses of known substance and new form of known substance that do not enhance 'efficacy"'. There is a high threshold for patent with regards to the term "inventive step" also various innovation procedural mechanism that may have helped examiners to identify the suspect patents as well as to create obstacles for applicant.

In order to increase access to medicine India has been successful to implement intellectual property rights to accomplish the same. There are various new and innovative flexibilities implemented by India under Section 3 of The Indian Patent Act when it revises its law in order to comply with TRIPS Agreement. It mentioned novel limitation on the subject matter with an exceptionally high inventive step standard procedural requirement and this could reduce the grant rate, a patent misuse standard that may be limit voluntary licensing activity and perhaps most strikingly constrain on injunctive remedies. The word inventive step was defined in the Patent Act as 'a feature

${ }^{33}$ Zoee Lynn Turrill, Finding the Patent Balance: The Novartis Glivec Case and the TRIPs Compliance of India's Section 3(D) Efficacy Standard , 44 Geo. J. Int'I L. 1555 2012-2013. 
that makes the invention non obvious to a person skilled in the art'34 [11]. Article 27.1 of the TRIPs agreement mentions that inventive step' is synonymous to "non obviousness". There are national patent offices that have practice guidelines explaining the primary proposal concerning what is non obvious to a 'person of ordinary skill' in a technological art in order to make an invention patentable. 'Technical advances as compared to existing knowledge' has the ability to dissolve the very basic requirement of 'obviousness/novelty'. If an invention is not very distinct from the prior art, it is not patentable ${ }^{35}$ [12]. These legal intricacies are provided with an aim to limit patents on new uses for already known product which does not enhance efficacy. This prevents companies to obtain successive patent and also a extended term protection on changes to a pharmaceutical that is not related to the drug's efficacy. The disclosure of additional information during the patent application process is required by Indian laws that are it required information that can both increase the accuracy of determinations in the patent office and decrease the grant rate. The claim of damages instead of injunctive relief as it encourages the generic companies to enter the market and invite infringement suits or license it whenever they could undercut the originator's price.

The implementation of Article 27.1 has caused a lot of complications with regards to various areas of patentability. As there is not strict interpretation of the various terms in Article 27.1 the countries can establish their own criteria on such terms. For instance, the term "inventive step" is used differently in different countries. Countries like India under Section 3(d) of Indian Patent Act had claimed a very strict interpretation of its term "inventive step". The Supreme Court ${ }^{36}[6]$ of India has mentioned that any improvement in already present drug may not amount to "inventive step".

There has been a mention that the subject matter patentability is granted for any invention if the product or the process in all the field of technology and all the product and the process that is new and involves inventive step and also which is useful or industrially applicable. Article 27.1 of TRIPS provides the requirement of the patent that shall be available for all types of product and process invention which is subject to principle of non discrimination. Thus the members of the country are not allowed to discriminate between the various fields of technology in their patent regime. The place of discrimination is also not allowed not considering the product to be imported or locally produced. The non discrimination includes with respect to place of invention, the field of technology and whether products are imported or locally produced. There is a general patentability obligation that applies to pharmaceutical industry. Article 27.1 has been interpreted by the member countries that are suitable to the society and also to the local laws ${ }^{37}$ [13]. "Discrimination means any form of differential treatment" is the most difficult interpretation. In order to comply by this there has to be "one size fits all" patent system that does not treat patents protecting different products differently. It is commented by commentators and industry groups that Article 27.1 has prohibited members from treating patentees in one single field of technology to the patentees in all the other fields that is, products and technology of one single field should be treated similar and not with other kinds. There are vast majority of patent law that may follow "technology neutrality" prima facie but Article 27.1 does not strictly require single level of IP

${ }^{34}$ Manoj Pillai, The Patent(Amendment) Act, 2005 and TRIPS Compliance- A critique, JIPR 10(3) 235-238.

${ }^{35} / d$.

${ }^{36}$ Novartis AG v. Union of India (2013) 6 SCC 1: (2013) 3 SCC (Civ) $227: 2013$ SCC Online SC 271 : (2013) 3 LW 449 (SC): AIR 2013 SC 1311

3714 B.U. J. Sci. \& Tech. L. 1772008 protection for all technologies or industries. Article 27.1 prohibits both de jure discrimination is widely accepted where an unjustified differentiation occurs in the manner of applying of the law. Thus there is a neutral exception where it may discriminate in order to violate Article 27.1 if it is raised repeatedly in respect of single technology such as pharmaceuticals. Hence the United States case KSR v. Teleflex ${ }^{38}$ [14] where the Supreme Court laid down the rules for non obviousness in designer and manufacturer of the adjustable pedals is applied to Takeda Chemical Industries, Ltd. v. Alphapharm Pty., Ltd. ${ }^{39}$ [15] case which is a pharmaceutical case relating to pharmaceutical drug which was granted non obvious to the asserted claimed patent. So the application of the test of obviousness does not differ between the fields of technologies. The rule of obviousness is same for all the products in United States. The case of Canada Pharmaceuticals ${ }^{40}$ [16] the WTO panel held that strict interpretation of Article 27.1 was rejected and prohibiting any differentiation between fields of technology.

The main objective of TRIPS is to impose minimum standard which is homogeneous to all the member states of $\mathrm{WTO}^{41}$ [17]. The patent balance of TRIPS is the standard that has been borrowed from United States $^{42}$. Due to this it has been objected by the developing countries that their interest is not taken into consideration. Thus in order to meet their needs the developing countries has to alter the TRIPS standard in order to meet their own. TRIPS is not perfectly implemented even though it is claimed that there is a clear mandate ${ }^{43}$. There are countries like India, Brazil and South Africa that has implemented patent law in compliance with TRIPS which complies with the pharmaceutical product and processes ${ }^{44}$. These countries were once the major exporters of the generic drugs of brand named patented product but this was banned after the introduction of TRIPS. It was only the least developed countries (LDCs) that could continue with the generic production. Thus the term "inventive step" in TRIPS is a minimum standard but it has different interpretation by different countries which can be strict or lenient compliance with TRIPS ${ }^{45}$. Therefore for the least developed countries it is a matter of choice to comply with a particular meaning to that term which can have strict or lenient interpretation, whichever is suitable for the country. The pharmaceutical companies fear the stricter interpretation of the term "inventive step" because getting patent will become difficult for them in such countries. Thus if least developing countries abided by strict interpretation like India it will pose a challenge for pharmaceutical companies.

There is an exception granted by TRIPS in order to harmonise substantive minimum standard for the protection of the intellectual property right, the establishment of a system in order to impose those rights intentionally and the duty to decide disputes under WTO dispute settlement procedure ${ }^{46}[18]$. TRIPS in case of patent protection shows a compromise between developed countries in order to see an increased obligation under the Paris Convention and the developing countries wanting an increased obligation in order to protect their national

\section{S. CT. 1727}

${ }^{39}$ No. 06-1329 (Fed. Cir. June 28, 2007)

${ }^{40}$ Panel Report, Canada-Patent Protection of Pharmaceutical Products, WT/DS 1 14/R (Mar. 17, 2000)

${ }^{41} \mathrm{M}$. Monirul Azam, The Experiences of TRIPs- Compliant Patent Law Reforms In Brazil, India, and South Africa and Lessons for Bangladesh, 7 Akron Intell. Prop. J. 61 2014-2015.

${ }^{42} \mathrm{Ibid}$

${ }^{43}$ Ibid

${ }^{44}$ Ibid.

${ }^{45}$ /bid

${ }^{46} /$ bid. 
intellectual property. In order to balance the public and private interest TRIPS tries to acknowledge it. After the negotiation of over five years the final TRIPS agreement was more favourable towards the developed countries as it elevated and harmonized the minimum standard of patent protection internationally that reflected the practices of developed countries and this imposed a new limitation on country's ability to not to grant protection to foreign patentees ${ }^{47}$ [19]. Therefore it can be inferred that the developing countries may not have standards as high as developed countries to enforce patent protection. This may lead not to grant protection to foreign patentees by the country. For instance if a particular drug is granted patent based on "inventive step" in country $\mathrm{X}$, it may not get patent protection for the same in country $\mathrm{Y}$ because the interpretation of "inventive step" differ from one country to other

The patent law in India is governed by the Indian Patent (Amendment) Act, 2005 which requires an invention to constitute an 'inventive step' which has to be advanced technically that the prior art or an economic significance or both ${ }^{48}$. The amendment to the Indian Patent Act was in the walk of the TRIPS Agreement which suffered from serious critics due to its ambiguity. Article 31(1) (i) of TRIPS dealt with compulsory licensing. Thus an invention was considered to be treated as 'inventive step' if it reflected an advancement of technology and if it has economic significance ${ }^{49}$ [20]. This kind of interpretation seemed absurd as economic significance and commercial success of an invention has not been served a basis for 'non obviousness' of claim. As there was no presence of any definition the guiding principle laid on TRIPS which ascertained the meaning and import of the terms. The standard of patentability has been lowered down.

The process of patenting of medicines is not at all new ${ }^{50}[6]$. Countries have different approaches towards this, while some countries have chosen to exempt medicines form the entire part of patent law while other countries like Canada and Australia have regimes that moderate the price mechanism to control price or facilitate local production under compulsory licenses. Countries that are developing like India, South Africa and Brazil have adopted other legal means to allow competitors to evade the negative effects of patent by allowing the patent of process and not of the product ${ }^{51}$. After the implementation of TRIPS Agreement under WTO countries like India, Brazil, and South Africa had two major concerns which is firstly, the local pharmaceutical's future and secondly, access to affordable medicines ${ }^{52}$. The reaction of countries towards TRIPs depends on the nature of pharmaceutical industry as that industry is important both economically and socially as some countries did not comply with TRIPS compliant ${ }^{53}$. Countries were confronted with the issue of how to manage the continued feasibility of the local pharmaceutical industry and provided entrance to affordable medicines while implementing TRIPS $^{54}[21]$.

In case of patent protection TRIPS compromises between a developed country which seeks to increase obligation under the

${ }^{47}$ Panel Report, Canada-Patent Protection of Pharmaceutical Products, WT/DS 1 14/R (Mar. 17, 2000).

${ }^{48}$ Ashish Pareek and Shivendra Singh, Concept of Obviousness: Scenario post KSR International v. Teleflex Inc., JIPR 13(1) (2008) 7-18.

${ }^{49} / \mathrm{bid}$.

${ }^{50}$ Supra note 47

${ }^{51}$ Supra note 48.

${ }^{52}$ /bid.

${ }^{53}$ lbid

${ }^{54}$ lbid.
Paris Convention and developing countries may seek to limit their obligations to protect intellectual property as per their national laws ${ }^{55}$. TRIPs agreement explicitly acknowledges its attempt to balance between private and public interests ${ }^{56}$. TRIPs agreement was highly favourable to developed countries as it uplifts and harmonises the minimum standard of patent protection internationally which reflected the practice of developed countries and imposed new limits on the ability of the country in order to deny foreign patentees ${ }^{57}$. For developing countries they already implemented TRIPs compliance patent law and they have also introduced patent protection for both pharmaceutical product and processes ${ }^{58}$ [22]. But the reasons for the grant of those patent protections differ from developed and developing country. For instance Novartis for its product Gleevec was granted patent in United States ${ }^{59}$ [23] and European Union but the patent was rejected in India.

Although developing countries play an extremely vital role as producers and exporters of generic copies of branded patented product but they can no longer do so because of introduction of TRIPS compliant patent regime in the countries ${ }^{60}$. Least Developed Country (LDC) could produce and export generic copies but only till January 1, 2016 now they have to abide by TRIPS. Due to Doha the LDCs got flexibility ${ }^{61}$. Later in 2013 this extension was exceeded to another eight years of extension permitting non compliance with TRIPS until $2021^{62}$. The transition period of LDCs concerns the entire TRIPs Agreement ${ }^{63}$. These extensions create potential export markets for the generic producers from LDCs ${ }^{64}$ [24]. Also in 2021 when TRIPS is compiled by LDCs the other countries sets an example for them to choose what kind of patentability is more suitable for their country. Thus cases like Novartis $^{65}$ [25] where Indian Supreme Court mentioned inventive step is not an improvement to the drug that is already in existence. TRIPS flexibilities used by India can be utilized by LDCs while adopting TRIPS compliant patent law.

\section{Interpretation and Implementation of Article 27.1 of TRIPs}

Article 27.1 was a provision that was neither mentioned in Paris Convention nor in any other national laws. Thus the discrimination that is currently banned was permissible for instance establishing different terms of patent protection as per the field of technology as it was provided in few of the domestic laws.

The main objective that the patent shall be available and the patent rights should be enjoyable without discrimination as to the place of invention. This had been an acceptance by the European Patent Convention.

${ }^{55}$ Maria Victoria Stout, Crossing The TRIPs Nondiscrimination Line: How CAFTA Pharmaceutical Patent Provisions Violate TRIPS Article 27.1, 14 B.U. J. Sci. \& Tech. L. 1772008

${ }^{56} /$ bid

${ }^{57}$ bid.

${ }^{58}$ Supra note 55

${ }^{59}$ US Patent Application No. 08/042,322. This application was abandoned and another continuation-in-part application was then filed on April 28, 1994 which matured into (US Patent 5,521,184)

${ }^{60}$ Supra note 58

${ }^{61} /$ bid.

${ }^{62} \mathrm{lbid}$.

${ }^{63}$ lbid.

${ }^{64}$ /bid

${ }^{65}$ Novartis AG v. Union of India (2013) 6 SCC 1: (2013) 3 SCC (Civ) $227: 2013$ SCC Online SC 271 : (2013) 3 LW 449 (SC): AIR 2013 SC 1311 
There are differential treatments was granted to patents depending on the country of invention in few countries. For instance, the Canadian regulation on was introduced in 1988 and it was in force until Bill C-91 was passed in February 1993.

TRIPS mentions that patent must be made available for all "inventions, whether product or processes" ${ }^{66}$ [26]. That is TRIPS Article 27.1 dissuade discrimination in the enjoyment of patent right between imported and locally produced products. The provision mentions:

"Subject to the provisions of paragraphs 2 and 3, patents shall be available for any inventions, whether products or processes, in all fields of technology, provided that they are new, involve an inventive step and are capable of industrial application.

Subject to paragraph 4 of Article 65, paragraph 8 of Article 70 and paragraph of this Article, patents shall be available and patent rights enjoyable without discrimination as to the place of invention, the field of technology and whether products are imported or locally produced".

TRIPS has transitional period in which the countries are required to bring their national legislation that complies with TRIPS provision. TRIPS specifies patents that must be available for all discoveries that “...are new, involves an inventive step and are capable of industrial application [27]. .7” $^{\text {” }}$

The difference between the number of new drug in the market that is developed globally each year and number of patents awarded for new uses of drug, processes, formulation, dosage form and different forms of same molecule including patents on gene and genomic sequences is huge ${ }^{68}$. As "new" and "inventive" are not defined and therefore countries must establish their own criteria for such terms ${ }^{69}$. The patentability standard shall be recognized which may be too wide and can contribute to "evergreening"70 [28]. "Evergreening" is making minimum amount of change to a drug especially for the one in which the patent is about to lapse, in order to gain a new patent that extends its manufacture's control over it. It is cheating on the implicit bargain of patent as the government backed monopoly is granted in exchange for invention that has entered into the public domain at the end of patent's lifetime [29]. ${ }^{71}$ The patent life for a new medicine is extended beyond the 20 years $^{72}$. Thus the Minister of Health of a country must work closely with other ministers in order to formulate or amend the national patent legislation in order to ensure that it takes public health needs into consideration ${ }^{73}$. The very recent case of Novartis $^{74}$ [30] where the Supreme Court of India has refused to allow patenting a new version of cancer drug. This was a major step forward for enabling poor people to access medicine in the developing countries. Novartis battled

${ }^{66}$ Alan O. Sykes, TRIPS, Pharmaceuticals, Developing Countries, and the Doha "Solution", 3ChilntlL47.pdf.

${ }^{67}$ TRIPS: Agreement on Trade-Related Aspects of Intellectual Property Rights, Apr. 15, 1994, Marrakesh Agreement Establishing the World Trade Organization, Annex 1C, THE LEGAL TEXTS: THE RESULTS OF THE URUGUAY ROUND OF MULTILATERAL TRADE NEGOTIATIONS 320 (1999), 1869 U.N.T.S. 299, 33 I.L.M. 1197 (1994) [hereinafter TRIPS Agreement] at Article 27 of TRIPS.

${ }^{68}$ Globalisation, TRIPS and Access to Pharmaceuticals, No.3 March 2001 World Health Organisation, Geneva

${ }^{69} / \mathrm{bid}$

${ }^{70} \mathrm{lbid}$

${ }^{71}$ Novartis AG v. Union of India (2013) 6 SCC 1: (2013) 3 SCC (Civ) $227: 2013$ SCC Online SC 271 : (2013) 3 LW 449 (SC): AIR 2013 SC 1311.

${ }^{72}$ Globalisation, TRIPS and Access to Pharmaceuticals, No.3 March 2001 World Health Organisation, Geneva.

${ }^{73}$ lbid.

${ }^{74}$ lbid. for six years after which the court ruled against it stating the minute changes and improvements to drug Glivec which did not amount to any innovation that deserved any patent. This ruling opened a whole new door for generic companies in India to manufacture and selling of cheap copies of the drug in the developing world and this implies HIV and other latest drugs.

Sometimes most likely for developed countries the interpretation is more stricter as the patent grant might be easier. On the other hand the interpretation in developing countries is lenient as the patent grant might be difficult. If it is looked form a different perspective then the developing countries has stricter interpretation as patent grant becomes difficult. Thus for this reason there has been evergreening included in various countries as patentability standard differs from country to country. Raising of standard in the existing patent grant especially the patents that is about to expire leads to evergreening that is there is an improvement in the prior art to grant patent. This depends on how a country determines inventive step in order to grant patent.

In order to promote a generic drug it requires an appropriate legislation and regulation professional and public acceptance of generic drugs, reliable quality assurance capacity, information from both prescribers and customers and economic incentives ${ }^{75}$. Generic labeling and allowing of generic substitute is not prevented by TRIPS Agreement ${ }^{76}$.

Trade liberalization leads to increase in competition and reduction of price for generic drugs that is already there in the market ${ }^{77}$. There may be consequences if the words and implementation of TRIPS compliant national legislation and regulations are inappropriate and introduction of new generic drug can be delayed ${ }^{78}$ [30]. Generic drugs can be facilitated by various ways such as drafting appropriate legislation and regularity on patentability and use of exception to exclusive rights that grant early testing and approval of generic and compulsory licensing ${ }^{79}$. This trickles down to the fact as to how a country interprets its laws and frames its laws in order to grant patent protection to a particular drug. This bring in the question of grant of patent on the basis of "inventive step" by a country by way of which there may a chance of production of generic drugs and a competitive market and if there is no inventive step there will be no patent granted. This may give a chance for destitute people to lay their hands on the drugs.

It is a human right to access essential drug for health concerns ${ }^{80}$. This depends on, firstly use of medicine and rational selection, secondly, sustainable adequate financing, thirdly, affordable prices and fourthly, supply system and reliable health ${ }^{81}$. Access to medicine is sensitive to the cost as most of the people in developing countries currently pay for medicines out of their own pocket ${ }^{82}$. The Government, United Nations, Civil Societies and Private Sectors all have a responsibility to achieve access to essential druggs ${ }^{83}$ [31].

TRIPS Agreement has enforced significant change for the protection
${ }^{75}$ Supra note 71
${ }^{76} / \mathrm{bid}$.
${ }^{77}$ lbid
${ }^{78} \mathrm{Ibid}$
${ }^{79}$ Novartis v. Union of India(2013) 6 SCC 1: (2013) 3 SCC (Civ) $227: 2013$ SCC Online SC 271 : (2013) 3 LW 449 (SC): AIR 2013 SC 1311
${ }^{80} /$ bid
${ }^{81}$ lbid.
${ }^{82} / \mathrm{bid}$
${ }^{83} \mathrm{lbid}$. 
of pharmaceutical product and process ${ }^{84}$. This made product patent protection binding to all Member countries, it also strengthened it ${ }^{85}$.

\section{Disputes relating to Article 27.1 of TRIPs}

The TRIPS Agreement has become an important tool in order to standardize the protection of pharmaceuticals in the world and this is actively sought by government of developed countries and also by big pharmaceutical companies ${ }^{86}$. The Agreement consists of various IPR issues in a manner that no international convention had dealt with previously including both substantive and enforcement rules in some area with considerable detail ${ }^{87}$.

Article 27 also forbids "discrimination as to place of invention" 88 [32]. The meaning of "discrimination" is setup or act on the basis of a distinction, or difference especially unfair on any of the grounds. ${ }^{89}$ It has established new standard for evaluating domestic law as the Paris Convention mandates only national treatment. National treatment has to focus on inventor's nationality as "discrimination as to place of invention" specifies the location of inventive activity ${ }^{90}$ [33].

In EU-Canada case ${ }^{91}$ [34] was regarding the TRIPS consistency with Section 55(2)(1) and(2) of Canadian Patent Act regarding the "early working", "regulatory review" or "Bolar" exception. The court pondered upon the meaning of "discrimination" and "differentiation". ${ }^{92}$ It makes it certain that the conduct prohibited under Article 27.1 of TRIPS is "discrimination" as to the field of technology. It stated that "discrimination" is not same as "differentiation" and that the WTO can adopt different rules for a particular product area when difference are adopted for different product area and difference are for bona fide purpose $^{93}$. Article 27.1 prohibits discrimination based on whether the invention is locally produced or imported.

In December 1997 the European Communities along with its member states requested a consultation with Canada as it was alleged that Canada violated Article 27.1 of TRIPS. It was contended by European Communities that under Canadian law the patent rights were discriminated against on the basis of the field of technology within the meaning of Article $27.1^{94}$. Though the panel did not find any violation under Article 27.1 as the challenged provision that is Section 55.2(1) of the Canadian law did not limit to pharmaceutical products but it was applicable to all the products that were subject to marketing approval requirements ${ }^{95}$ [35]. Although the decision of the panel was based on findings on Article 27.1 but it refused to provide a definition of what "discrimination" meant.

"Discrimination" as to the place of invention specifies the place of the inventive activity of the product. TRIPS does not allow for such

${ }^{84}$ Lauren A. Degnan, Does U.S. Patent Law Comply with TRIPS Article 3 and 27 with Respect to the Treatment of Inventive Activity, 78 J. Pat. \& Trademark Off. Soc'y 1081996.

${ }^{85} \mathrm{Ibid}$.

${ }^{86} \mathrm{lbid}$.

${ }^{87}$ lbid.

${ }^{88} \mathrm{lbid}$.

${ }^{89}$ The Concise Oxford Dictionary, p. 274.

${ }^{90}$ Supra note 88.

${ }^{91} \mathrm{WT} / \mathrm{DS} 114 / \mathrm{R}$.

92Patent: Non Discrimination, http://www.iprsonline.org/unctadictsd/docs/RB2.5 Patents_2.5.2_update.pdf, (last updated on 30 June 2016 at 12:30 AM)

${ }^{93} /$ bid.

${ }^{94} \mathrm{lbid}$

${ }^{95}$ Ibid. discrimination. This discrimination cannot be on the basis of the product imported or locally produced. The grant of patent criteria will not differ. Discrimination is not accepted but differences are acceptable. It is also stated that differences are for bona fide reason that is, differentiating treatment between medicine and software products is accepted. So the treatment may different from one product to another. For instance the case of Canada Pharmaceuticals ${ }^{96}$ [31] the WTO panel held that strict interpretation of Article 27.1 was rejected and prohibiting any differentiation between fields of technology [34].

The interpretation of Article 27.1 on "discrimination means any form of differential treatment" is also restrictive ${ }^{97}[36]$. The member establishes "one size fits all" patent system and it does not treat patents protecting food and medicines differently than devices and software. Article 27.1 prohibits members from treating patentees in one field of technology unfavorably relative to patentees in field of other technologies. After the case of Canada Pharmaceuticals ${ }^{98}$ [11] the WTO panel held that strict interpretation of Article 27.1 was rejected and prohibiting any differentiation between field of technology. Article 27.1 prohibits both de jure discrimination and de facto discrimination. Thus it was conclude that it would be discriminatory only if Article 27.1 is invoked repeatedly with respect to a single technology such as pharmaceuticals. Therefore the use of the term "inventive step" may differ from one product technology to another as per the country.

The WTO Trade Related Aspect of Intellectual Property Right Agreement was out to set out minimum standard in order to protect intellectual property that includes patent for pharmaceuticals has been criticized by various countries because it resulted in the increase level of patent protection on drug prices. This has become a problem as the demands of TRIPS seemed elevated for developing countries. Thus a transition period was given to developing and least developing countries in order to implement TRIPS provisions in their national laws.

Implementation of Article 27.1 caused a lot of ciaos relating to the various areas of patentability. As Article 27.1 has not provided for any strict interpretation of various jargons used in the Article for instance, "inventions", "new", "inventive step" and "field of technologies" etc. Thus countries get a chance to establish their own criteria or such terms. The question arises while implementation of such terms by the countries. "Discrimination as to place of invention" also raised question regarding the place of invention and also using as a prior art in other country.

The Indian Patent Act, 2005 had retained the old definition of 'invention' provided in Section 2(1) (j) but in addition to that it provides a definition on 'new invention'. 'New invention' states any invention or technology that has not been foreseen by publication in any document or used in the country or elsewhere in the world before the filing date of a patent application with entire specification of the subject matter which is not in public domain or which does not form a part of state of art. The main question was that whether the definition of 'new invention' applied same as the 'invention' under Section 2(1) (j). If it does then does it comply with Article 27 of the TRIPS Agreement.

In the task of the latest amendment to the Indian Patent Act 1970

${ }_{96}^{96}$ Panel Report, Canada-Patent Protection of Pharmaceutical Products, WT/DS 1 14/R (Mar. 17, 2000).

${ }^{97}$ Lauren A. Degnan, Does U.S. Patent Law Comply with TRIPS Article 3 and 27 with Respect to the Treatment of Inventive Activity, 78 J. Pat. \& Trademark Off. Soc'y 1081996.

${ }^{98}$ Supra note 96 
the Indian Commerce Minister pushed through the latest amendment in the Parliament of India in 2005, March in order for it to comply with TRIPS ${ }^{99}$. There was an Expert constituency to review contention which was if it would violate the TRIPS Agreement if India excludes 'nonNCE (New Chemical Entities) pharmaceutical product inventions' from patentability. Thus the issue in front of the committee was that if the patentability can only be limited to the New Chemical Entity which has more than one or more therapeutic use which does not violate TRIPs. In other words, would it be a violation of TRIPs if India excludes a verity of inventions around a NCE having one or more therapeutic combination. Article 27 of TRIPS does not allow member countries to discriminate patentability and non patentability invention with respect to (i) field of technology (ii) place of invention (iii) domestic production as against importation.

The New Medical Entities are not limited to patentability of pharmaceutical inventions under the amended Indian Patent Act, 1970. In order to increase the threshold of patentability there has to be a higher standard of 'novelty' and 'inventive step' and by excluding additional categories of subject matters from patentability ${ }^{100}$ [37]. For instance the new definition of inventive step under Section 2(1) (1) and the amended definition for 'pharmaceutical substance' which is Section 2(1)(ta) is an additional new explanation and expansion to Section 3(d) in general were the objective is stepping up the threshold of patentability in general. The amended definition redefined 'pharmaceutical substance' stating it to be a new entity which involved one or more inventive step ${ }^{101}$. The amended Patent Act, 1970 had permitted patentability of a number of pharmaceutical substance which is not NCEs or NMEs. If there is a chance of complying it with TRIPs then Indian Patent Law would violate the Agreement if Indian Patent law would expressly exclude non-NCE pharmaceutical invention from patentability ${ }^{102}$. The definition of 'inventive step' is free to be defined by TRIPs Members in such a way that it may exclude almost everything other than NCEs from the scope of patentability. There is a possibility that there is a higher standard of 'non obviousness' required and connection to Section 3(d) to justify the exclusion of non-NCE pharmaceutical invention from patentability ${ }^{103}$.

Under Article 27 of TRIPS it is mandatory for the grant of patent to be new, have inventive step and be capable of industrial application and Section 3(d) of the Indian Patent Act would violate this provision as it supports discriminatory provision as it states:

"The mere discovery of a new form of a known substance which does not result in the enhancement of the known efficacy of that substance or the mere discovery of any new property or new use for a known substance or of the mere use of a known process, machine or apparatus unless such known process results in a new product or employs at least one new reactant."

The later explanation mentions that the derivatives of the known substance are not patentable unless they differ "significantly" in properties with respect to efficacy. If there is an agreement on interpretation of the term 'significantly' which may eliminate the possibility of subjective interpretations then this section may rule out the grant of patent also for the products that is derived from a known substance ${ }^{104}[38]$.

${ }_{9}^{9}$ Manoj Pillai, The Patent(Amendment) Act, 2005 and TRIPS Compliance- A critique, JIPR 10(3) 235-238.

${ }^{100} \mathrm{Ibid}$.

${ }^{101}$ Supra note 99

${ }^{102} /$ bid.

${ }^{103}$ /bid.

${ }^{104}$ Ibid.
The question of inventive step is put forward in order to examine the new derivatives of existing molecule. There are different interpretations regarding the significance of the improvement which is the subjective decision.

\section{Conclusion}

One can conclude that the challenge is to find out the correct guideline that interprets "inventive step" in its true meaning. There are various ways in with this word is interpreted by different countries. TRIPS have provided flexibility to the term of inventive step. Thus the country can interpret this as per their convenience and the needs of the society. The countries will know about the minimum requirement for it to abide by TRIPs. We see a number of disputes arising when it comes to Article 27.1 of TRIPs agreement as there are difference that arises due to interpretation. This interpretation is very clear about inventive step with regards to defining it as it falls on the nation to have its clauses laid down. But there has been disputes that arose relating to Article 27.1 that involved inventive step. Thus there were cases like EU-Canada case which dealt with the interpretation of Article 27.1 in the light of inventive step. Thus one can notice when it deals with the Article there are cases that has interpreted it clearly that it fits the benefit of all the nation. Sometimes most likely for developed countries the interpretation is more stricter as the patent grant might be easier. On the other hand the interpretation in developing countries is lenient as the patent grant might be difficult. If it is looked form a different perspective then the developing countries has stricter interpretation as patent grant becomes difficult. The condition of patentability of 'non-obviousness' finds its place around the world due to Article 27.1 of TRIPs. Although there are noticeable difference when it comes to define the meaning of the term of 'inventive step' among the countries. As dealt in the article there is various number of cases that there are varieties to implement Article 27.1 of TRIPS's inventive step such as not discriminating in terms of inventive step on the basis of product. There are cases in which countries mostly developing as well as LDC have to change their rules according to the time line of the Convention which when expires the countries looses the privilege it acquired and has to comply by TRIPs for instance the amendment of 2005 in the Indian Patent Act, 1970. Thus there are various interpretations to inventive step and it depends on country to country and which rule to follow making the competition in such aspect either too high or too low for the pharmaceutical industry.

\section{References}

1. Ellen FM, Hoen T (2003) TRIPS, Pharmaceutical Patents and Access to Essential Medicines: Seattle, Doha and Beyond 11: 39

2. Balasingham B (2011) Trade in Pharmaceuticals Under the TRIPs Agreement 11 U. C. Dublin L. Rev. 1. 2: 1-25.

3. Chisum DS (2006) Patentability Under TRIPS: The Need for Uniformity, The Indian Journal of Law and Technology 2: 1-4.

4. Patents: Subject Matter and Patentability Requirements, CY564-Unctad-v1 November 29, 2004

5. https://www.wto.org/english/thewto_e/whatis_e/tif_e/org6_e.htm

6. Stout MV (2008) Crossing The TRIPs Nondiscrimination Line: How CAFTA Pharmaceutical Patent Provisions Violate TRIPS Article 27.1, 14 B.U. J Sci \& Tech L 177.

7. Vandoren P (2002) TRIPS: An EU Perspective, 7 Int'I Intell Prop L \& Pol'y 79-1

8. Land M (2011-2012) Rebalancing TRIPS, 33 Mich. J. Int'I L. 433.

9. Supra note 31

10. Turrill ZN (2013) Finding the Patent Balance: The Novartis Glivec Case and 
the TRIPs Compliance of India's Section 3(D) Efficacy Standard, 44 Geo. J. Int'l L. 1555.

11. Pillai M (2005) The Patent (Amendment) Act, 2005 and TRIPS Compliance- A critique, JIPR 10: 235-238.

12. Novartis AG v. Union of India (2013) 6 SCC 1: (2013) 3 SCC (Civ) 227: 2013 SCC Online SC 271 : (2013) 3 LW 449 (SC): AIR 2013 SC 1311.

13. 127 S. CT. 1727

14. Conlin DG ( 2007) United States Court of Appeals for the Federal Circuit No. 06-1329 (Fed. Cir. June 28, 2007), USA.

15. Panel Report (2000) Canada-Patent Protection of Pharmaceutical Products, WT/DS 1 14/R

16. Azam MM (2015) The Experiences of TRIPs- Compliant Patent Law Reforms In Brazil, India, and South Africa and Lessons for Bangladesh, 7 Akron Intell. Prop. J. 61.

17. Panel Report (2000) Canada-Patent Protection of Pharmaceutical Products, WT/DS 1 14/R (Mar. 17).

18. Pareek A, Singh S (2008) Concept of Obviousness: Scenario post KSR International v. Teleflex Inc., JIPR 13: 7-18.

19. Supra note 47.

20. Supra note 48 .

21. US Patent Application No. 08/042,322. This application was abandoned and another continuation-in-part application was then filed on April 28, 1994 which matured into US Patent 5,521,184.

22. Supra note 58

23. Novartis AG v. Union of India (2013) 6 SCC 1: (2013) 3 SCC (Civ) 227: 2013 SCC Online SC 271: (2013) 3 LW 449 (SC): AIR 2013 SC 1311.

24. Sykes AO (2002) TRIPS, Pharmaceuticals, Developing Countries, and the Doha "Solution", University of Chicago Law School Chicago Unbound, USA.
25. TRIPS: Agreement on Trade-Related Aspects of Intellectual Property Rights, Apr. 15, 1994.

26. Marrakesh Agreement Establishing the World Trade Organization, Annex 1c the legal texts: the results of the uruguay round of multilateral trade negotiations 320 (1999), 1869 U.N.T.S. 299, 33 I.L.M. 1197 (1994) [hereinafter TRIPS Agreement] at Article 27 of TRIPS.

27. Globalisation (2001) TRIPS and Access to Pharmaceuticals, No.3 March World Health Organisation, Geneva

28. Globalisation, TRIPS and Access to Pharmaceuticals, No.3 March 2001 World Health Organisation, Geneva.

29. Supra note 71

30. Novartis v. Union of India(2013) 6 SCC 1: (2013) 3 SCC (Civ) 227: 2013 SCC Online SC 271: (2013) 3 LW 449 (SC): AIR 2013 SC 1311.

31. Degnan LA (1996) Does U.S. Patent Law Comply with TRIPS Article 3 and 27 with Respect to the Treatment of Inventive Activity, J. Pat. \& Trademark Off. Soc'y 78:108.

32. The Concise Oxford Dictionary, pp. 274

33. WT/DS114/R

34. Patent: Non Discrimination (2004), Article 27.1 Patentable Subject Matter, CY564-Unctad-v1.

35. Panel Report, Canada-Patent Protection of Pharmaceutical Products, WT/DS 1 14/R (Mar. 17, 2000).

36. Supra note 96

37. Supra note 99

38. WT/DS114/R (2000) Canada- patent protection of pharmaceutical Products, Complaint by the European Communities and their member States Report of the panel, World Trade Organization.
This article was originally published in a special issue, International Intellectual Property Law and Its Role in Dispute Resolution handled by Editor. Michael D VanAuker, Faculty of Law University of Pittsburgh, San Francisco, USA 